\title{
GAMBARAN SEBARAN TENAGA ELEKTROMEDIK \\ DI RUMAH SAKIT WILAYAH PROVINSI KALIMANTAN SELATAN MEGGUNAKAN SISTEM INFORMASI GEOGRAFIS
}

\section{Description Of Electromedical Staff Hospital Area In South Borneo Province Using Geographic Information System}

\author{
Rusdiansyah, Muhammad Akbar Hariyono, Galih Persadha \\ Politeknik Unggulan Kalimantan, Program Studi D3 Teknik Elektromedik \\ Email: akbar.hariyono@polanka.ac.id ${ }^{2}$
}

\begin{abstract}
South Borneo Province as the oldest province in Borneo Island, fact various data and information related to health workers, especially those related to facilities / infrastructure and certain health personnel in a hospital or community health center are still very minimal to obtain so that the general public is difficult to know where he can get the best health based on the availability of adequate facilities / infrastructure and health workers based on the range of locations where he lives. Retrieval of data by means of a survey, which is an investigation conducted to obtain electromedical staff data and mapping of electromedical staff needs in the Province of South Borneo. The timing of the research was carried out for 4 (four) months, starting from November 2016 to March 2017. Almost all hospitals in the South Borneo Province have a lack of electromedical staff and estimates of the fulfillment of electromedical staff needs in South Borneo are estimated to range from 10 to 15 years. With the existence of a geographic information system, information on electromedical staff in South Kalimantan can be more easily accessed by the community.
\end{abstract}

\section{Keywords : electromedical, south borneo, Geographic Information System}

\begin{abstract}
ABSTRAK
Propinsi Kalimantan Selatan sebagai propinsi tertua di kalimantan, pada kenyataannya berbagai data dan informasi terkait tenaga kesehatan, terutama yang berkaitan dengan sarana/prasarana serta tenaga kesehatan tertentu pada sebuah rumah sakit atau pusat kesehatan masyarakat masih sangat minim untuk diperoleh sehingga masyarakat umum sulit untuk mengetahui dimana ia bisa mendapatkan kesehatan yang terbaik berdasarkan ketersediaan sarana/prasarana yang memadai maupun tenaga kesehatan berdasarkan jangkauan lokasi tempat tinggalnya. Pengambilan data dilakukan dengan cara survey, yaitu penyelidikan yang dilakukan untuk memperoleh data tenaga elektromedik serta pemetaan kebutuhan tenaga elektromedik di Provinsi Kalimantan Selatan. Waktu pelaksanaan penelitian dilaksanakan selama 4 (empat) bulan yaitu mulai bulan November 2016 hingga Maret 2017. Hampir semua Rumah sakit di wilayah Provinsi Kalimantan Selatan mempunyai kekurangan tenaga elektromedis dan estimasi pemenuhan kebutuhan tenaga elektromedis di Kalimantan Selatan diperkiran berkisar 10 sampai dengan 15 tahun kedepan. Dengan adanya sistem informasi geografis, informasi tenaga elektromedis di Kalimantan selatan dapat lebih mudah diakses oleh masyarakat.
\end{abstract}

Kata kunci : elektromedik, kalimantan selatan, sistem informasi geografis 


\section{PENDAHULUAN}

Salah satu indikator dari Indeks Pembangunan Manusia adalah indeks kesehatan yang dalam pencapainnya memerlukan upaya akselerasi peningkatan status dan ketersedian tenaga medis di dalam masyarakat. Sejalan dengan tujuan pembangunan kesehatan yakni percepatan pencapaian derajat kesehatan masyarakat yang optimal, maka pemerintah daerah di seluruh wilayah Indonesia senantisa berupaya mendekatkan kesehatan kepada masyarakat melalui berbagai tenaga kesehatan yang merata, terjangkau dan bermutu (BAPPENAS, 2009). Pelayanan penunjang dalam upaya kesehatan saat ini sangat diperlukan yaitu pelayanan untuk teknik elektromedik yang merupakan bagian integral dari pelayanan kesehatan. Pelayanan elektromedik telah mengalami perkembangan yang pesat baik dari sisi keilmuan maupun teknologi rekayasa pada bidang kedokteran/kesehatan seiring dan sejalan dengan era globalisasi.

Saat ini banyak alat-alat kesehatan di rumah sakit (RS), baik negeri maupun swasta yang mubazir atau tidak bisa terawat dengan baik. Hal ini karena tidak adanya tenaga profesional yang dapat merawat dan mengoperasikan dengan baik, sehingga kegunaan alat-alat kesehatan tersebut belum bisa dimanfaatkan secara maksimal. Peran dan tanggung jawab profesi elektromedik tidak sebatas merawat saja, tetapi termasuk di dalamnya merencanakan pembelian sesuai kebutuhan, mengawasi, mengembangkan, mengevaluasi efektivitas alat yang sudah dibeli serta mengevaluasi teknologi yang dipergunakan. Dalam UU Pendirian Rumah Sakit maupun dalam UU Kesehatan disebutkan, sebuah RS harus memiliki tenaga teknik yang dapat merawat atau memelihara peralatan kesehatan yang dimiliki. Kebutuhan ideal yang dimaksud, sebuah RS tipe A harus memiliki minimal 9 tenaga teknik Elektromedik.

Saat ini jumlah lulusan Elektromedik di Indonesia berdasarkan data IKATEMI baru tersedia lebih kurang sekitar 4.500 orang yang tersebar di RS negeri, swasta maupun profesi lain di lingkungan instansi kesehatan lainnya. Di sisi lain, perkembangan teknologi informasi yang cepat dan kemudahan dalam mengakses informasi melalui perangkat teknologi informasi, memungkinkan ketersediaan informasi tentang tenaga kesehatan yang dapat diakses secara cepat, akurat dan up to date. Propinsi Kalimantan Selatan sebagai propinsi tertua di kalimantan, pada kenyataannya berbagai data dan informasi terkait tenaga kesehatan, terutama yang berkaitan dengan sarana/prasarana serta tenaga kesehatan tertentu pada sebuah rumah sakit atau pusat kesehatan masyarakat masih sangat minim untuk diperoleh sehingga masyarakat umum sulit untuk mengetahui dimana ia bisa mendapatkan kesehatan yang terbaik berdasarkan ketersediaan sarana/prasarana yang memadai maupun tenaga kesehatan berdasarkan jangkauan lokasi tempat tinggalnya. Adapun dampak bagi pemerintah adalah sulitnya memvisualisasikan sebaran sarana/prasarana serta tenaga kesehatan yang ada, sehingga mengakibatkan pada kurang optimalnya pengambilan keputusan untuk pengembangan bidang kesehatan.

Mengatasi permasalahan tersebut, teknologi SIG (Sistem Informasi Geografis) dapat membantu pengguna dalam hal ini masyarakat umum dan pemerintah untuk dapat melihat informasi sebaran lokasi tenaga elektromedik di wilayah Provinsi Kalimantan Selatan dengan lebih mudah, cepat, interaktif dan atraktif.

\section{METODE PENELITIAN}

Penelitian ini merupakan penelitian non eksperimental dan dilaksanakan dengan metode deskriptif. Pengambilan data dilakukan dengan cara survey, yaitu penyelidikan yang dilakukan untuk memperoleh data tenaga elektromedik serta pemetaan kebutuhan tenaga elektromedik di Provinsi Kalimantan Selatan. Waktu pelaksanaan penelitian dilaksanakan selama 4 (empat) bulan yaitu mulai bulan November 2016 hingga Maret 2017. Secara detail tahapan penelitian diuraikan sebagai berikut : 


\section{Pengumpulan Data}

Untuk membangun sistem informasi geografis tenaga kesehatan berbasis web, diperlukan data spasial dan data atribut. Data spasial adalah data geografis wilayah seperti koordinat peta, jalan, maupun lokasi rumah sakit, gambar, suara dan sebagainya. Data atribut berupa data hasil dari form kuisoner yang dibagikan kepada pihak rumah sakit di wilayah Propinsi Kalimantan Selatan. Kedua jenis data tersebut selanjutnya akan digunakan untuk membuat database spasial yang merupakan sumber data dari sistem informasi geografis yang akan dibuat. Hasil akhir dari tahapan ini adalah terkumpulnya data geografis wilayah dan data atribut yang nantinya akan digunakan pada tahap pengolahan data dan perancangan SIG.

\section{Analisis Data}

Proses ini ditunjukkan untuk menganalisis rasio tenaga kesehatan terhadap suatu nilai tertentu. Hasil form kuisioner dilakukan analisis data secara deskriptif.

\section{Perancangan Sistem}

Pada tahap ini, data hasil survey lapangan dan hasil analisis kemudian diklasifikasi kedalam dua jenis, yaitu data spasial berupa peta administrasi provinsi Kalimantan Selatan dan data atribut berupa titik koordinat tenaga elektromedik, kebutuhan rasio tenaga elektromedik, dan posisi rumah sakit.

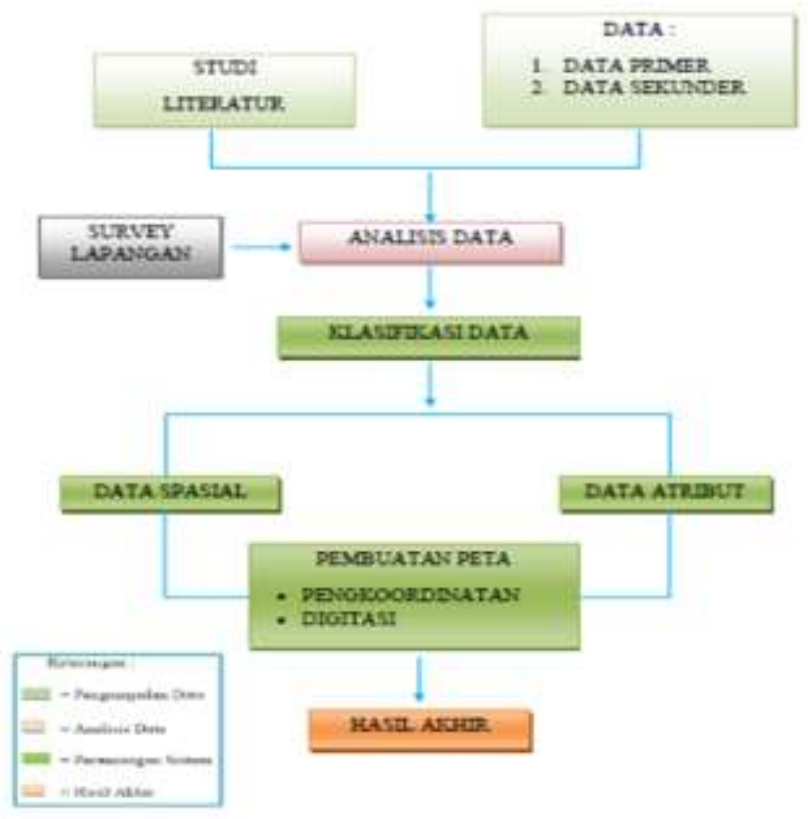

Gambar 1. Alur Penelitian

\section{HASIL DAN PEMBAHASAN}

\subsection{Analisis Kebutuhan Tenaga Elektromedik}

Perhitungan Perencanaan SDM ini menggunakan Daftar Susunan Pegawai (DSP / Authorized Staffing List) atau WISN (Work Load Indikator Staff Need). Metode yang digunakan dalam penelitian ini adalah Daftar Susunan Pegawai (DSP / Authorized Staffing List).

Prosedur perhitungan kebutuhan SDM Teknik Elektromedik berdasarkan DSP ini bisa digunakan di berbagai unit kerja seperti puskesmas, rumah sakit dan sarana kesehatan lainya. Berikut ini adalah contoh DSP Rumah Sakit dengan bermacam-macam model : 
1. Model Rumah Sakit Tipe A sebagai rujukan tertinggi atau disebut pula sebagai rumah sakit pusat.

2. Model Rumah Sakit Tipe B yang didirikan di setiap ibukota Propinsi yang menampung pelayanan rujukan di rumah sakit kabupaten.

3. Model Rumah Sakit Tipe C yang didirikan disetiap ibukota Kabupeten yang pelayanan rujukan dari puskesmas.

4. Model Rumah Sakit Tipe $D$ atau rumah sakit yang bersifat transisi dengan kemampuan hanya memberikan pelayanan kedokteran umum dan gigi.

5. Model Rumah Sakit Tipe E yang menyelenggarakan hanya satu macam pelayanan kedokteran saja.

Tabel 1. Model DSP Rumah Sakit

\begin{tabular}{|c|c|c|c|}
\hline No & Model DSP RS & Formasi Jabatan & Jumlah \\
\hline \multirow[t]{2}{*}{1} & Rumah Sakit Tipe A & Tenaga Elektromedis Terampil & 24 \\
\hline & & $\begin{array}{l}\text { Tenaga Elektromedis } \\
\text { Ahli }\end{array}$ & 12 \\
\hline \multirow[t]{2}{*}{2} & Rumah Sakit Tipe B & Tenaga Elektromedis Terampil & 24 \\
\hline & & $\begin{array}{l}\text { Tenaga Elektromedis } \\
\text { Ahli }\end{array}$ & 12 \\
\hline \multirow[t]{2}{*}{3} & Rumah Sakit Tipe C & Tenaga Elektromedis Terampil & 12 \\
\hline & & $\begin{array}{l}\text { Tenaga Elektromedis } \\
\text { Ahli }\end{array}$ & 6 \\
\hline \multirow[t]{2}{*}{4} & Rumah Sakit Tipe D & Tenaga Elektromedis Terampil & 2 \\
\hline & & $\begin{array}{l}\text { Tenaga Elektromedis } \\
\text { Ahli }\end{array}$ & 1 \\
\hline \multirow[t]{2}{*}{5} & Rumah Sakit Tipe E & Tenaga Elektromedis Terampil & 3 \\
\hline & & $\begin{array}{l}\text { Tenaga Elektromedis } \\
\text { Ahli }\end{array}$ & 1 \\
\hline
\end{tabular}

\subsection{Data Tenaga Elektromedis Kota Banjarmasin}

Berdasarkan data yang diperoleh, ada 10 rumah sakit (RS) yang tersebar di kota Banjarmasin. Data ditunjukkan pada Tabel 2.

Tabel 2. Analisis Tenaga Elektromedis Kota Banjarmasin

\begin{tabular}{clcccc}
\hline No. & Rumah Sakit & $\begin{array}{c}\text { Model } \\
\text { DSP }\end{array}$ & $\begin{array}{c}\text { Jumlah } \\
\text { Formasi } \\
\text { Ideal }\end{array}$ & $\begin{array}{c}\text { Jumlah Tenaga } \\
\text { Elektromedis }\end{array}$ & Status \\
\hline 1 & RSUD Ulin & 1 & 36 & 3 & Kurang \\
\hline 2 & $\begin{array}{l}\text { RSUD Dr. H. Moch. Ansari } \\
\text { Saleh }\end{array}$ & 2 & 36 & 2 & Kurang \\
\hline 3 & RS Suaka Insan & 3 & 18 & 0 & Kurang \\
\hline 4 & RS Sari Mulia & 3 & 18 & 0 & Kurang \\
\hline 5 & RS Islam Banjarmasin & 3 & 18 & 1 & Kurang \\
\hline 6 & RS Bhayangkara & 3 & 18 & 0 & Kurang \\
\hline 7 & RS Ciputra & 3 & 18 & 1 & Kurang
\end{tabular}


ISSN 2656-7733

Volume 1 No. 1 (April, 2019)

\begin{tabular}{clllll}
\hline 8 & RS TPT Dr. R. Soeharsono & 5 & 4 & 0 & Kurang \\
\hline 9 & RS Khusus Bedah Siaga & 5 & 4 & 0 & Kurang \\
\hline 10 & RS Bersalin Ibunda Siti & 5 & 4 & 0 & Kurang \\
\hline
\end{tabular}

\subsection{Data Tenaga Elektromedis Kota Banjarbaru}

Kotamadya Banjarbaru memiliki 5 rumah sakit yang rinciannya dijabarkan dalam tabel 3.

Tabel 3. Analisis Tenaga Elektromedis Kota Banjarbaru

\begin{tabular}{clcccc}
\hline No. & Rumah Sakit & Model DSP & $\begin{array}{c}\text { Jumlah } \\
\text { Formasi } \\
\text { Ideal }\end{array}$ & $\begin{array}{c}\text { Jumlah Tenaga } \\
\text { Elektromedis }\end{array}$ & Status \\
\hline 1 & RSUD Banjarbaru & 3 & 18 & 1 & Kurang \\
\hline 2 & RS Syifa Medika & 4 & 3 & 0 & Kurang \\
\hline 3 & $\begin{array}{l}\text { RS TNI AU Syamsudin } \\
\text { Noor }\end{array}$ & 4 & 3 & 0 & Kurang \\
\hline 4 & $\begin{array}{l}\text { RS TK. IV Guntung } \\
\text { Payung }\end{array}$ & 4 & 3 & 0 & Kurang \\
\hline 5 & RS Mawar & 4 & 3 & 0 & \\
\hline
\end{tabular}

\subsection{Data Tenaga Elektromedis Kab. Banjar}

Kabupaten Banjar mempunyai 5 rumah sakit (RS) yang dirincikan dalam tabel 4.

Tabel 4. Analisis Tenaga Elektromedis Kabupaten Banjar

\begin{tabular}{clcccc}
\hline No. & Rumah Sakit & $\begin{array}{c}\text { Model } \\
\text { DSP }\end{array}$ & $\begin{array}{c}\text { Jumlah } \\
\text { Formasi } \\
\text { Ideal }\end{array}$ & $\begin{array}{c}\text { Jumlah Tenaga } \\
\text { Elektromedis }\end{array}$ & Status \\
\hline 1 & RSUD Ratu Zalecha & 3 & 18 & 1 & Kurang \\
\hline 2 & RSJD Sambang Lihum & 5 & 8 & 2 & Kurang \\
\hline 3 & RS Avicenna Medika & 4 & 3 & 0 & Kurang \\
\hline 4 & RS Pelita Insani & 4 & 3 & 0 & Kurang \\
\hline 5 & RS PTPN XIII Danau Salak & 4 & 3 & 0 &
\end{tabular}

\subsection{Data Tenaga Elektromedis Kab. Tapin, HSS dan HST}

Kabupaten Tapin hanya mempunyai 1 rumah sakit umum daerah dan tidak terdapat adanya rumah sakit swasta di wilayah kabupaten ini. 
Tabel 5. Analisis Tenaga Elektromedis Kabupaten Tapin

\begin{tabular}{clcccc}
\hline No. & Rumah Sakit & Model DSP & $\begin{array}{c}\text { Jumlah Formasi } \\
\text { ldeal }\end{array}$ & $\begin{array}{c}\text { Jumlah Tenaga } \\
\text { Elektromedis }\end{array}$ & Status \\
\hline 1 & $\begin{array}{l}\text { RSUD Datu } \\
\text { Sanggul }\end{array}$ & 3 & 18 & 3 & Kurang \\
\hline
\end{tabular}

Kabupaten Hulu Sungai Selatan mempunyai 4 rumah sakit (RS), dimana 3 diantaranya adalah milik swasta seperti yang ditunjukkan dalam Tabel 6 dibawah ini.

Tabel 6. Analisis Tenaga Elektromedis Kabupaten Hulu Sungai Selatan

\begin{tabular}{clcccc}
\hline No. & Rumah Sakit & Model DSP & $\begin{array}{c}\text { Jumlah } \\
\text { Formasi ldeal }\end{array}$ & $\begin{array}{c}\text { Jumlah Tenaga } \\
\text { Elektromedis }\end{array}$ & Status \\
\hline 1 & $\begin{array}{l}\text { RSUD Brigjend H. } \\
\text { Hasan Basry }\end{array}$ & 3 & 18 & 3 & Kurang \\
\hline 2 & $\begin{array}{l}\text { RS Pahlawan } \\
\text { Medical Centre }\end{array}$ & 4 & 3 & 0 & Kurang \\
\hline 3 & $\begin{array}{l}\text { RS Ceria } \\
\text { Kandangan }\end{array}$ & 4 & 3 & 0 & Kurang \\
\hline 4 & RS Pratama & 4 & 3 & 0 & Kurang \\
\hline
\end{tabular}

Kabupaten Hulu Sungai Tengah hanya mempunyai 1 rumah sakit umum daerah (RSUD).

Tabel 7. Analisis Tenaga Elektromedis Kabupaten Tapin

\begin{tabular}{clcccc} 
No. & Rumah Sakit & Model DSP & $\begin{array}{c}\text { Jumlah } \\
\text { Formasi ldeal }\end{array}$ & $\begin{array}{c}\text { Jumlah Tenaga } \\
\text { Elektromedis }\end{array}$ & Status \\
\hline 1 & RSUD H, & 3 & 18 & 2 & Kurang \\
\hline
\end{tabular}

\subsection{Data Tenaga Elektromedis Kab. HSU, Tabalong dan Tanah Laut}

Kabupaten Hulu Sungai Utara mempunyai 1 rumah sakit umum daerah dan 1 rumah sakit swasta seperti data yang ditujukkan pada Tabel 8.

Tabel 8. Analisis Tenaga Elektromedis Kabupaten Hulu Sungai Utara

\begin{tabular}{clcccc}
\hline No. & Rumah Sakit & Model DSP & $\begin{array}{c}\text { Jumlah } \\
\text { Formasi ldeal }\end{array}$ & $\begin{array}{c}\text { Jumlah Tenaga } \\
\text { Elektromedis }\end{array}$ & Status \\
\hline 1 & $\begin{array}{l}\text { RSUD Pambalah } \\
\text { Batung }\end{array}$ & 3 & 18 & 0 & Kurang \\
\hline 2 & RS Mulia & 4 & 3 & 0 & Kurang
\end{tabular}

Kabupaten Tabalong mempunyai 1 rumah sakit umum daerah dan 1 rumah sakit milik BUMN.

Tabel 9. Analisis Tenaga Elektromedis Kabupaten Tabalong

\begin{tabular}{clcccc}
\hline No. & Rumah Sakit & Model DSP & $\begin{array}{c}\text { Jumlah } \\
\text { Formasi ldeal }\end{array}$ & $\begin{array}{c}\text { Jumlah Tenaga } \\
\text { Elektromedis }\end{array}$ & Status \\
\hline 1 & $\begin{array}{l}\text { RSUD H. } \\
\text { Badaruddin }\end{array}$ & 3 & 18 & 2 & Kurang \\
\hline
\end{tabular}


$\begin{array}{llllll}2 & \text { RS Pertamina } & 4 & 3 & 0 & \text { Kurang }\end{array}$

Kabupaten Tanah Laut hanya mempunyai 1 rumah sakit umum daerah (RSUD) sebagaimana dalam Tabel 10.

Tabel 10. Analisis Tenaga Elektromedis Kabupaten Tanah Laut

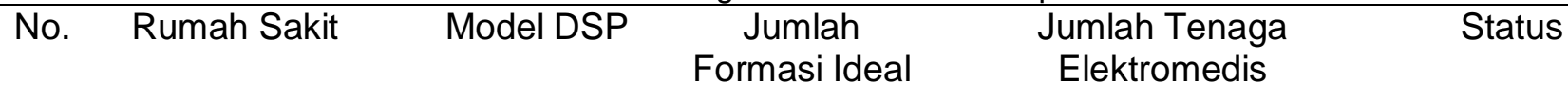

$\begin{array}{llllcl}1 & \begin{array}{l}\text { RSUD H. } \\ \text { Boejasin }\end{array} & 3 & 18 & 3 & \text { Kurang }\end{array}$

\subsection{Data Tenaga Elektromedis Kab.Tanah Bumbu, Kotabaru, Balangan dan Barito Kuala}

Kabupaten Tanah Bumbu mempunyai 1 rumah sakit umum daerah dan 1 rumah sakit swasta sebagaimana ditunjunkkan dalam Tabel 11.

Tabel 11. Analisis Tenaga Elektromedis Kabupaten Tabalong

\begin{tabular}{clcccc}
\hline No. & Rumah Sakit & $\begin{array}{c}\text { Model } \\
\text { DSP }\end{array}$ & $\begin{array}{c}\text { Jumlah } \\
\text { Formasi Ideal }\end{array}$ & $\begin{array}{c}\text { Jumlah Tenaga } \\
\text { Elektromedis }\end{array}$ & Status \\
\hline 1 & $\begin{array}{l}\text { RSUD dr. H. Andi } \\
\text { Abdurrahman Noor }\end{array}$ & 3 & 18 & 0 & Kurang \\
\hline 2 & $\begin{array}{l}\text { Marina Permata } \\
\text { Hospital }\end{array}$ & 4 & 3 & 0 & Kurang \\
\hline
\end{tabular}

Kabupaten Kotabaru, Kabupaten Barito Kuala dan Kabupaten Balangan hanya mempunyai 1 rumah sakit umum daerah dan tidak terdapat adanya rumah sakit swasta di wilayah kabupaten ini. Tabel 12 merupakan hasil analisis tenaga elektromedis Kabupaten Kotabaru dan Tabel 13 merupakan hasil analisis tenaga elektromedis Kabupaten Balangan. Terakhir, hasil tenaga elektromedis Kabupaten Barito Kuala ditunjukkan pada Tabel 14.

Tabel 12. Analisis Tenaga Elektromedis Kabupaten Kotabaru

\begin{tabular}{cccccc}
\hline No. & Rumah Sakit & Model DSP & $\begin{array}{c}\text { Jumlah } \\
\text { Formasi Ideal }\end{array}$ & $\begin{array}{c}\text { Jumlah Tenaga } \\
\text { Elektromedis }\end{array}$ & Status \\
\hline 1 & RSUD Kotabaru & 3 & 18 & 1 & Kurang
\end{tabular}

Tabel 13. Analisis Tenaga Elektromedis Kabupaten Balangan

\begin{tabular}{cccccc}
\hline No. & Rumah Sakit & Model DSP & $\begin{array}{c}\text { Jumlah } \\
\text { Formasi Ideal }\end{array}$ & $\begin{array}{c}\text { Jumlah Tenaga } \\
\text { Elektromedis }\end{array}$ & Status \\
\hline 1 & RSUD Balangan & 3 & 18 & 1 & Kurang \\
\hline
\end{tabular}

Tabel 14. Analisis Tenaga Elektromedis Kabupaten Barito Kuala

\begin{tabular}{clcccc}
\hline No. & Rumah Sakit & Model DSP & $\begin{array}{c}\text { Jumlah Formasi } \\
\text { Ideal }\end{array}$ & $\begin{array}{c}\text { Jumlah Tenaga } \\
\text { Elektromedis }\end{array}$ & Status \\
\hline 1 & RSUD H. & 4 & 3 & 0 & Kurang \\
& Abdul Aziz & & & & \\
\hline
\end{tabular}


Berdasarkan data dari sejumlah tabel diatas dapat diketahui bahwa :

1. Hampir semua rumah sakit di wilayah Provinsi Kalimantan Selatan mempunyai kekurangan tenaga elektromedis.

2. Terdapat tiga rumah sakit kabupeten yaitu RSUD H. Abdul Aziz (Kabupaten Barito Kuala), RSUD dr. H. Andi Abdurrahman Noor (Kabupaten Tanah Bumbu) dan RSUD Pambalah Batung (Kabupaten Hulu Sungai Utara) yang tidak mempunyai tenaga elektromedis.

Tabel 15 menunjukkan data rekapan jumlah kebutuhan tenaga elektromedis Provinsi Kalimantan Selatan.

Tabel 15. Rekapan Jumlah Kebutuhan Tenaga Elektromedis Provinsi Kalimantan Selatan

\begin{tabular}{|c|c|c|c|}
\hline & & Analisis Kebutuhan Tenag & Elektromedis \\
\hline No & Kabupaten / Kota & Jumlah RS Tenaga Tersedia & $\begin{array}{c}\text { Alokasi Kebutuhan } \\
\text { Tenaga }\end{array}$ \\
\hline
\end{tabular}

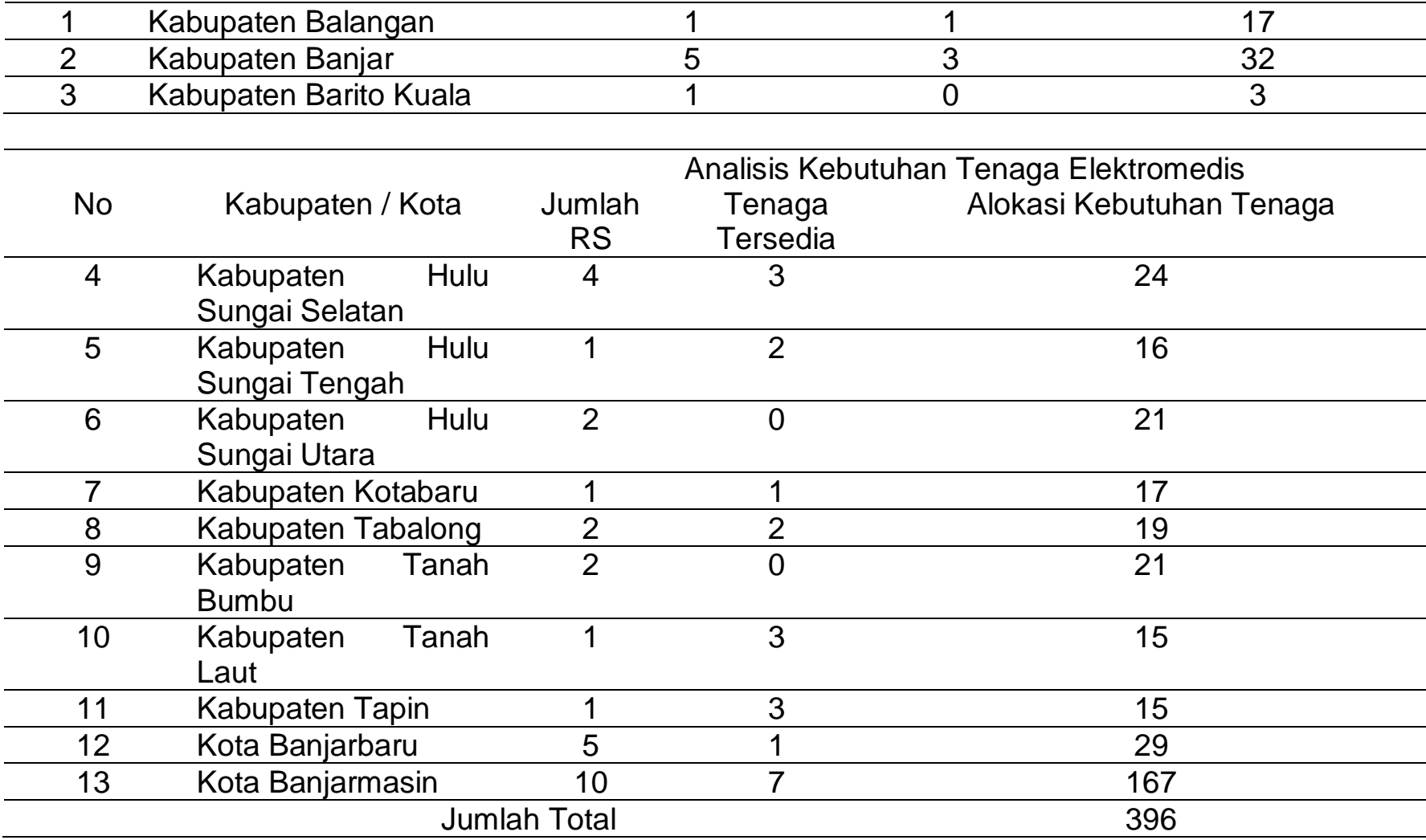

Di Kalimantan selatan, institusi penyelenggara pendidikan teknik elektromedik adalah Politeknik Unggulan Kalimantan. Dalam Tabel 20 di bawah ini menjelaskan Analisa pemenuhan kebutuhan teknik elektromedik selama beberapa tahun kedepan berdasarkan data alumni mahasiswa teknik elektromedik Politeknik Unggulan Kalimantan. 
Volume 1 No. 1 (April, 2019)

Tabel 20. Data Lulusan Teknik Elektromedik Politeknik Unggulan Kalimantan

No. Tahun Kelulusan Jumlah Lulusan Jumlah Total Kebutuhan Tenaga

Elektromedis

\begin{tabular}{llll}
\hline 1 & Tahun 2018 & 30 & 396 \\
\hline 2 & Tahun 2019 & 17 & 366 \\
\hline 3 & Tahun 2020 & 40 & 349 \\
\hline 4 & Tahun 2021 & 40 & 309 \\
\hline
\end{tabular}

\subsection{Perancangan Digitasi Peta Sistem Informasi Geografis (SIG)}

Digitasi adalah proses mengkonversi obyek geografis dari peta analog / cetak ke format digital. Metode digitasi yang digunakan pada penelitian ini adalah metode on screen digitizing menggunakan tools Quantum GIS. Sistem Informasi Geografis (SIG) sebaran tenaga Elektromedis di Rumah Sakit Wilayah Kalimantan Selatan dapat diakses di alamat: https://www.google.com/maps/d/u/0/edit?mid=1IWv0mEcRRe4a31rEbd7hVyd-Wyl\& Il=2.2002810282882104\%2C115.15913728359374\&Z=8.

Visualisasi Peta SIG Rumah Sakit di Wilayah Kalimantan Selatan ditunjukkan dalam Gambar 2.

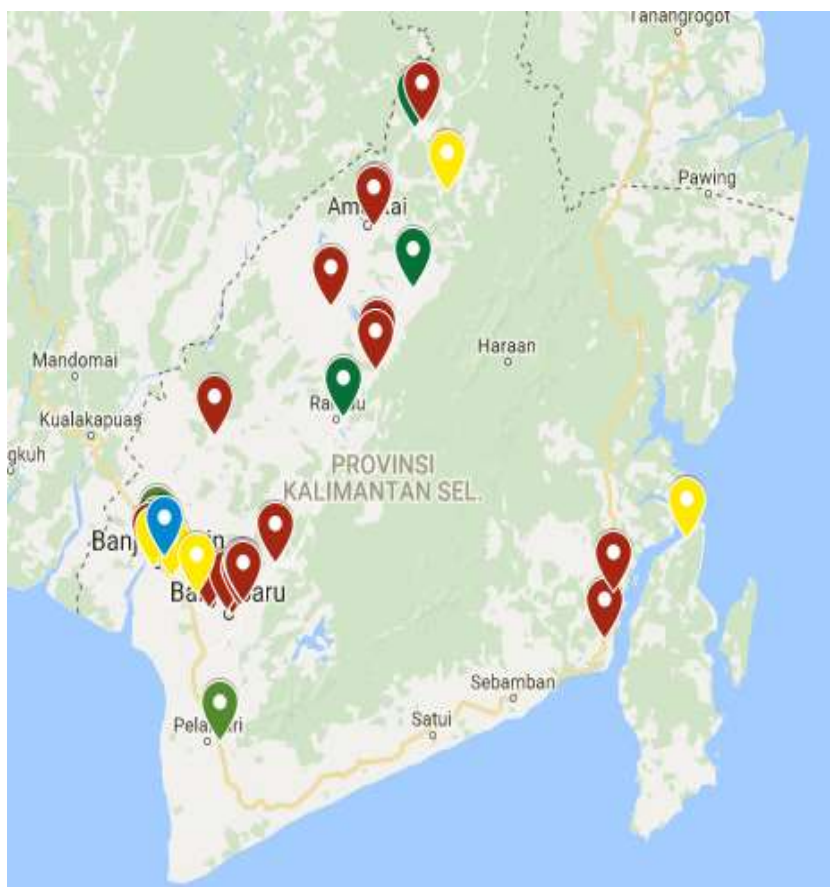

Gambar 2. Digitasi Peta Rumah Sakit Wilayah Kalimantan Selatan 
Visualisasi Peta SIG Rumah Sakit di Kota Banjarmasin ditunjukkan pada Gambar 3.

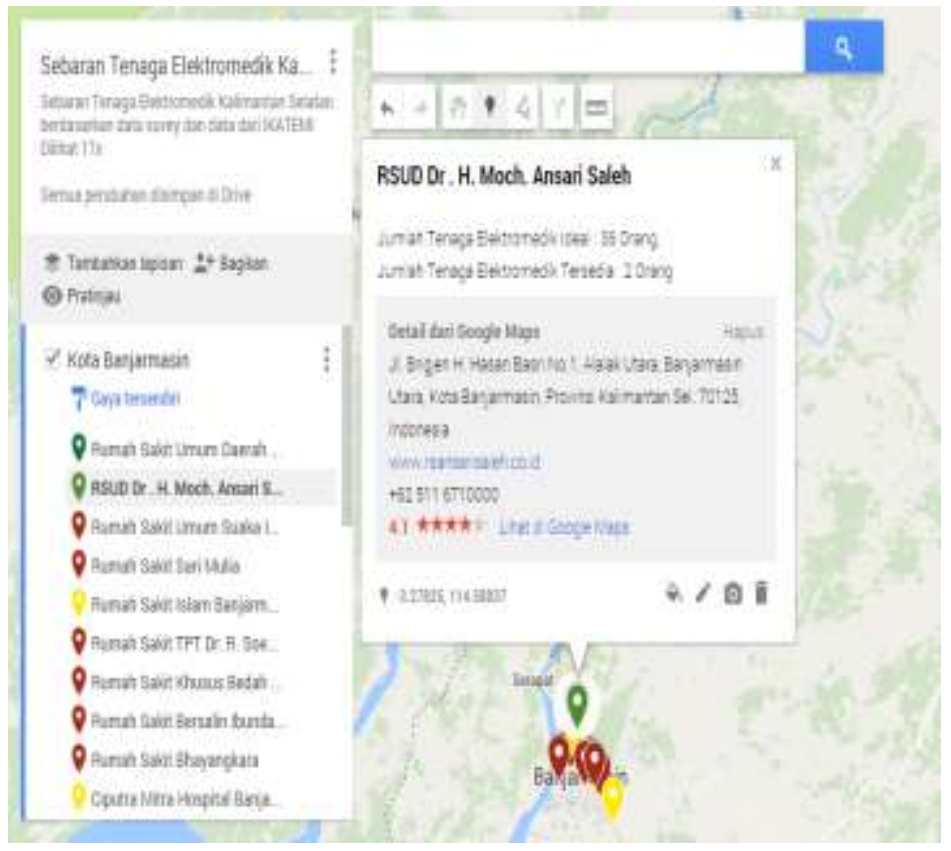

Gambar 3. Digitasi Peta Rumah Sakit Wilayah Kota Banjarmasin

\section{KESIMPULAN DAN SARAN}

\subsection{Kesimpulan}

1. Jumlah kekurangan tenaga elektromedis di Rumah Sakit Wilayah Provinsi Kalimantan Selatan adalah 396 orang.

2. Terdapat 3 rumah sakit pemerintah di wilayah Provinsi Kalimantan Selatan yang tidak mempunyai tenaga elektromedis yaitu yaitu RSUD H. Abdul Aziz (Kabupaten Barito Kuala), RSUD dr. H. Andi Abdurrahman Noor (Kabupaten Tanah Bumbu) dan RSUD Pambalah Batung (Kabupaten Hulu Sungai Utara).

3. Estimasi pemenuhan kebutuhan tenaga elektromedis di Kalimantan Selatan diperkiran berkisar 10 sampai dengan 15 tahun kedepan.

4. Dengan adanya sistem informasi geografis, informasi tenaga elektromedis di Kalimantan selatan dapat lebih mudah diakses oleh masyarakat.

5. Sistem Informasi Geografis (SIG) sebaran tenaga Elektromedis di Rumah Sakit Wilayah Kalimantan Selatan dapat diakses di alamat website:

https://www.google.com/maps/d/u/0/edit?mid=1IWv0mEcRRe4a31rEbd7hVyd-Wyl\& Il=$\underline{2.2002810282882104 \% 2 C 115.15913728359374 \& \mathrm{z}=8}$ 


\subsection{Saran}

1. Perlu diadakan pemerataan kembali terhadap kebutuhan tenaga elektromedis pada kabupaten / kota di wilayah Provinsi Kalimantan Selatan.

2. Tampilan dari Perancangan peta Sistem Informasi Geografis sebaiknya dikembangkan berbentuk tampilan 3 Dimensi (3D).

\section{DAFTAR PUSTAKA}

Alhaliki, Budiyanto. "Pemetaan sarana dan prasarana di Kota Gorontalo menggunakan Sistem Informasi Geografis (SIG)”. Skripsi. Teknik Informatika Universitas Negeri Gorontalo, 2012.

BAPPENAS. 2009. Pembanguan Propinsi Gorontalo : Perencanaan dengan Indeks Pembangunan Manusia. Building and Reinventing Decentralized Governance.

Kaswidjanti ,Wilis. Santosa, Budi. Wicaksono, R.S. "Sistem Informasi Geografis Pemetaan Tenaga Kesehatan Di Kota Magelang Berbasis Web". Seminar Nasional Informatika UPN "Veteran" Yogyakarta, 24 Mei 2008.

Koniyo, Muhammad Hidayat, Agus Lahinta. "Analisis dan Pemetaan Tenaga Kesehatan Menggunakan Sistem Informasi Geografis. Laporan Penelitian. Prodi Teknik Informatika Universitas Negeri Gorontalo, 2012.

Sadoun, Balqies. Saleh, Bassam. "A Geographic Information System (GIS) to Define Indicators for Development and Planning in Jordan”. Proceedings e-Bussiness (ICE-B). 2 